\title{
Peningkatan Motivasi dan Hasil Belajar Melalui Model Problem Based Learning
}

\author{
Rizky Ayudhityasari \\ Universitas Veteran Bangun Nusantara \\ dhityarizk31@gmail.com
}

\begin{abstract}
Abstrak
Tujuan penelitian ini untuk meningkatkan motivasi dan hasil belajar Bahasa Indonesia kelas III Sekolah Dasar Negeri 2 Bolopleret. Penelitian ini merupakan penelitian tindakan kelas. Subjek penelitian adalah siswa sekolah dasar kelas III yang berjumlah 25 siswa. Pengumpulan data menggunakan teknik dokumentasi, observasi, angket dan tes. Validitas data menggunakan teknik triangulasi sumber dan triangulasi metode. Analisis data dilakukan secara deskriptif baik secara kualitatif maupun kuantitatif. Hasil penelitian sebagai berikut: (1) Motivasi belajar siswa yang berkategori "tinggi" yang awalnya pada siklus I sebesar 64\% atau 16 siswa. Pada siklus II menjadi 92\% atau 23 siswa. 2) Hasil belajar siswa sebelum tindakan hanya mencapai $32 \%$ atau 8 siswa yang tuntas. Setelah tindakan pada siklus I, sebanyak 11 siswa atau sebesar 44\% belum mencapai ketuntasan belajar, 14 siswa atau sebesar 56\% telah tuntas. Siklus II meningkat menjadi 4 siswa atau sebesar 16\% belum tuntas, 21 siswa atau sebesar $84 \%$ telah tuntas. Sehingga dapat disimpulkan bahwa model problem bases learning dapat meningkatkan motivasi dan hasil belajar siswa.
\end{abstract}

Kata kunci: bahasa Indonesia, hasil belajar, motivasi, problem based learning

\begin{abstract}
The purpose of this study was to increase motivation and learning outcomes of third grade Indonesian at elementary school Negeri 2 Bolopleret. This research is a classroom action research. The research subjects were the third grade students, totaling 25 students. Data collection uses documentation, observation, questionnaire and test techniques. The validity of the data using source triangulation techniques and method triangulation. Data analysis was carried out descriptively, both qualitatively and quantitatively. The results of the study are as follows: (1) The learning motivation of students who are categorized as "high" in the first cycle is $64 \%$ or 16 students. In the second cycle to $92 \%$ or 23 students. 2) Student learning outcomes before the action only reached $32 \%$ or 8 students who completed. After the action in the first cycle, as many as 11 students or 44\% have not finished studying, 14 students or 56\% have completed. Cycle II increased to 4 students or 16\% incomplete, 21 students or $84 \%$ completed. So that, it Will be concluded that the problem bases learning model can increase the motivation and the student's results.
\end{abstract}

Keywords: Indonesian language, learning outcomes, motivation, problem based learning

https://doi.org/.

Copyright (C) 2021, Rizky Ayudhityasari This is an open-access article under the CC-BY License. 


\section{PENDAHULUAN}

Berdasarkan Surat Edaran Nomor 4 Tahun 2020 tentang Pelaksanaan Kebijakan Pendidikan dalam masa darurat penyebaran virus, Mendikbud menghimbau agar semua lembaga pendidikan tidak melakukan proses belajar mengajar secara langsung melainkan harus dilakukan secara tidak langsung atau jarak jauh. Dengan adanya himbauan tersebut membuat semua lembaga pendidikan mengganti metode pembelajaran yang digunakan yaitu menjadi online atau dalam jaringan (daring).

Dengan perubahan dalam proses pembelajaran menyebabkan terjadinya perubahan, siswa dan guru yang sebelumnya berinteraksi secara langsung sekarang harus berinteraksi dalam ruang virtual. Guru dituntut memberikan pengajaran yang baik sehingga menciptakan suasana yang kondusif untuk belajar dan secara kreatif dan inovatif agar dapat membantu siswa memahami materi pembelajaran dan tujuan pembelajaran dapat tercapai walaupun pembelajaran dilakukan secara daring. Selain itu, terjadinya perubahan pada siswa juga berpengaruh terhadap motivasi belajarnya.

Hasil observasi awal pembelajaran daring di kelas III SD Negeri 2 Bolopleret semester II tahun pelajaran 2020/2021 masih banyak melalui platform WhatsApp untuk pemberian tugas maupun materi. Pada pelaksanaan pembelajaran melalui vicon belum disiapkan secara matang, penjelasan materi masih berfokus pada kegiatan menyimak materi dan pemberian tugas. Sehingga pengalaman belajar siswa kurang maksimal. Saat pembelajaran melalui vicon siswa tidak memperhatikan penjelasan guru, asik berbicara dengan temannya, ketika guru memberikan kesempatan bertanya tidak ada siswa yang bertanya, kurang semangat dalam mengikuti pembelajaran dan siswa mengumpulkan tugas tidak tepat waktu.

Motivasi belajar yang rendah tersebut berpengaruh terhadap hasil belajar siswa selama pembelajaran daring khususnya pada muatan pelajaran Bahasa Indonesia. Data dari hasil penilaian harian dari 25 siswa terdapat 17 siswa dengan persentase 68\% yang masih memiliki nilai dibawah KKM yang ditetapkan yaitu 67 dan yang tuntas KKM hanya 8 siswa dengan persentase 32\%. Kondisi yang diharapkan bahwa siswa kelas III memiliki motivasi berkategori tinggi dengan nilai motivasi belajar siswa minimal 70 sehingga berpengaruh pada pencapaian hasil belajar IPA diatas KKM yaitu 66. Pelaksanaan pembelajaran daring dimaksimalkan dengan video conference. Khususnya pada muatan pelajaran Bahasa Indonesia yang memerlukan kreativitas guru untuk mengembangkan materi pembelajarannya.

Adanya kesenjangan antara harapan dengan kenyataan, maka peneliti memberi solusi atas permasalahan tersebut dengan model problem based learning untuk meningkatkan motivasi dan hasil belajar siswa. Menurut Rahmadani \& Anugraheni (2017:241-250) Problem Based Learning merupakan pendekatan pembelajaran yang menggunakan permasalahan dunia nyata sebagai suatu konteks, untuk mengembangkan kemampuan berfikir kritis serta kemampuan pemecahan masalah siswa dalam memahami konsep dan prinsip yang esensi dari materi pelajaran. Selanjutnya, menurut Rahmawati \& Hizqiyah (2017:23) dalam PBL, siswa dihadapkan pada suatu permasalahan, selanjutnya secara berkelompok, siswa akan berdiskusi untuk mencari solusi atas permasalahan tersebut untuk mendapatkan solusinya.

Fakhriyah (2014) dalam penelitiannya mengungkapkan beberapa kelebihan penerapan problem based learning meliputi pembahasan materi yang sangat luas, diskusi yang berjalan sangat aktif serta mampu mengembangkan kemampuan berpikir kritis. Menurut Fakhriyah (2014) kelemahan problem based learning ialah: langkah pembelajaran yang tidak dapat dilaksanakan dalam waktu singkat. Penerapan problem based learning membutuhkan waktu yang cukup lama, pembelajaran mengharuskan 
aktivitas belajar mandiri setiap siswa, serta terkadang masih ada beberapa siswa yang mengandalkan teman satu kelompoknya.

Penelitian ini juga didukung oleh penelitian yang telah dilakukan Maria (2021) bahwa pengimplementasian model pembelajaran problem based learning sesuai dengan indikator motivasi belajar dimana siswa dituntut untuk bekerja sama dan berdiskusi. Hasil penelitian menunjukkan problem based learning dapat meningkatkan kemampuan hasil belajar pada siswa serta dapat memotivasi siswa menjadi aktif, kreatif dan inovatif dalam menyampaikan suatu pendapat atau gagasan yang siswa tersebut ingin sampaikan.

Auliah Sumitro, dkk (2017) dalam penelitiannya mengungkapkan bahwa penerapan model problem based learning dapat meningkatkan motivasi dan hasil belajar IPS siswa kelas IV SD Inpres Bangkala III Kota Makassar. Terjadi peningkatan motivasi siswa pada keempat aspek dengan rincian, pada aspek attention meningkat sebesar $11,28 \%$ dari $73,04 \%$ pada siklus I menjadi $84,32 \%$ pada siklus II, pada aspek relevance meningkat sebesar $9,64 \%$ dari $76,55 \%$ pada siklus I menjadi $86,19 \%$ pada siklus II, pada aspek confidence meningkat sebesar $10,62 \%$ dari $71,56 \%$ pada siklus I menjadi $82,18 \%$ pada siklus II, dan pada aspek satisfaction meningkat sebesar 14,88\% dari 71,79\% pada siklus I menjadi $86,67 \%$ pada siklus II. Hasil belajar kognitif juga mengalami peningkatan sebesar $14,29 \%$ dari 78,94\% pada siklus I menjadi $85,96 \%$ pada siklus II.

Berdasarkan uraian diatas permasalahan yang muncul antara lain motivasi belajar siswa yang rendah yang berpengaruh pada hasil belajar siswa sehingga peneliti bertujuan menggunakan menggunakan model problem based learning untuk meningkatkan motivasi dan hasil belajar pada pembelajaran daring muatan pelajaran Bahasa Indonesia kelas III SD Negeri 2 Bolopleret tahun pelajaran 2020/2021.

\section{METODE PENELITIAN}

Jenis penelitian ini adalah penelitian tindakan kelas (PTK). Penelitian ini dilakukan di SD Negeri 2 Bolopleret, Kecamatan Juwiring, Kabupaten Klaten tahun pelajaran 2020/2021. Penelitian dilakukan dalam dua siklus. Penelitian ini dilaksanakan secara kolaborasi antara peneliti dan guru kelas. Subyek penelitian ini siswa kelas III SD Negeri 2 Bolopleret yang terdiri dari 25 siswa. Objek dalam penelitian ini adalah peningkatan motivasi dan hasil belajar Bahasa Indonesia melalui penerapan model problem based learning kelas III SD Negeri 2 Bolopleret tahun pelajaran 2020/2021.

Prosedur pelaksanaan PTK meliputi: perencanaan, pelakasanaan tindakan, pengamatan, dan refleksi (Arikunto, 2010; 137).

Teknik pengumpulan data yang digunakan adalah: (a) angket (b) observasi (c) tes (d) dokumentasi. Dalam penelitian ini angket digunakan untuk mengumpulkan informasi terkait motivasi belajar siswa setelah tindakan. Observasi dilakukan untuk mengamati aktivitas guru dan siswa untuk mengevaluasi setiap tindakan untuk meningkatkan proses pembelajaran dengan instrumen lembar observasi. Tes hasil belajar digunakan untuk mengukur pengetahuan siswa terhadap materi pembelajaran yaitu muatan pelajaran Bahasa Indonesia pada setiap pertemuan. Dokumentasi dilaksanakan guna memperkuat data setelah observasi dan mengumpulkan informasi terkait data sekolah seperti: profil sekolah, daftar nama siswa, dan hasil belajar siswa.

Teknik analisis data menggunakan teknik analisis model interaktif yang dikembangkan oleh Huberman (dalam Yanto 2013:68) terdiri atas tiga komponen yaitu reduksi data, beberan (dislay) data, dan penarikan kesimpulan. Analisis data kuantitatif dilakukan secara deskriptif. 
Teknik triangulasi digunakan untuk mengecek keabsahan data pada penelitian ini. Triangulasi yang digunakan yakni triangulasi sumber dan triangulasi metode. Triangulasi sumber ini dilakukan peneliti dengan membandingkan data-data dari guru dan siswa. Sedangkan triangulasi metode berupa data yang diperoleh dari angket, tes, observasi dan dokumentasi.

Indikator keberhasilan pada penelitian ini telah ditentukan sebagai berikut: 1) Motivasi belajar siswa kelas III dari 25 siswa pada akhir siklus yang berkategori tinggi yaitu minimal berjumlah 20 siswa atau 80\% 2) Hasil belajar siswa kelas IV dari 25 siswa pada akhir siklus persentase jumlah siswa yang tuntas KKM pada muatan pelajaran IPA minimal 80\% atau sebanyak 20 siswa dan persentase yang belum tuntas KKM maksimal $20 \%$ atau sebanyak 5 siswa.

\section{HASIL DAN PEMBAHASAN}

Kondisi awal proses pembelajaran kelas III masih didominasi oleh kegiatan ceramah dan tanya jawab yaitu menjelaskan tentang materi dan siswa hanya mendengarkan serta memperhatikan contoh yang diberikan. Hal tersebut dikarenakan pembelajaran daring merupakan hal yang baru bagi guru dan siswa.

Muatan Pelajaran Bahasa Indonesia merupakan materi yang cukup memerlukan pemahaman dikarenakan pada kelas rendah muatan pelajaran Bahasa Indonesia sebagai jembatan untuk memahami materi lainnya. Hal tersebut membuat siswa tidak dapat sepenuhnya menjawab soal dengan benar dalam bentuk pilihan ganda atau pun uraian. Pada kegiatan evaluasi, siswa kurang dapat memahami soal yang cukup panjang dan memerlukan analisis. Metode pembelajaran yang demikian membuat penyusunan langkah pembelajaran yang kurang sesuai dengan materi.

Hal tersebut juga menyebabkan motivasi belajar siswa rendah. Ditunjukkan dengan siswa tidak memperhatikan penjelasan guru, asik berbicara dengan teman, siswa kurang mempunyai rasa ingin tahu yang mendalam terhadap materi, kurang antusias saat menjawab pertanyaan atau bertanya dan siswa mengumpulkan tugas tidak tepat waktu. Motivasi belajar tersebut berpengaruh terhadap hasil belajar muatan pelajaran siswa kelas IV SD Negeri 2 Bolopleret. Diperoleh data awal bahwa yang belum mencapai ketuntasan belajar sebanyak 17 siswa (68\%).

Penelitian tidakan kelas ini dilaksanakan pada kelas III yang terdiri dari 25 siswa di SD Negeri 2 Bolopleret. Pelaksanaan tindakan dalam penelitian kelas ini terdiri dari 2 siklus setiap pertemuan 2x35 menit. Kegiatan dilakukan secara daring melalui zoom. Kegiatan dilakukan secara daring melalui google meet. Setiap siklus terdiri dari 4 kegiatan yaitu perencanaan, pelaksanaan, observasi/pengamatan, dan refleksi

Pembelajaran siklus I dilaksanakan pada tanggal 6 April 2021. Pada penyampaian kegiatan siklus I, peneliti menggunakan model pembelajaran Problem Based Learning atau pembelajaran berbasis masalah yang meliputi perencanaan, pelaksanaan, hasil penelitian, observasi, dan refleksi.

Setelah diadakannya tindakan siklus I diperoleh hasil motivasi dan hasil belajar siswa yang meningkat daripada sebelum tindakan. Persentase motivasi belajar siswa yang berkategori "tinggi" sebesar 64\% atau 16 siswa. Seiring dengan meningkatnya motivasi siswa berpengaruh pula terhadap hasil belajar siswa. Setelah tindakan pada siklus I, sebanyak 11 siswa atau sebesar 44\% belum mencapai ketuntasan belajar, 14 siswa atau sebesar 56\% telah tuntas. Hal tersebut menunjukkan kenaikan yang cukup signifikan.

Pembelajaran siklus II dilaksanakan pada tanggal 8 April 2021. Pada penyampaian kegiatan siklus II, peneliti menggunakan model pembelajaran problem based learning 
atau pembelajaran berbasis masalah yang meliputi perencanaan, pelaksanaan, hasil penelitian, observasi dan refleksi.

Pada pelaksanaan siklus II media yang dibuat lebih simpel dengan menampilkan teks, beberapa gambar, video, dan animasi sehingga mudah dipahami. Siswa lebih antusias pada kegiatan pembelajaran terlihat dalam menyampaikan pertanyaan, pendapat maupun ide. Guru telah berusaha menciptakan suasana belajar yang santai, menyenangkan, dan terkendali. Proses pembelajaran pada siklus II lebih meningkatkan pemahaman siswa terhadap materi pembelajaran.

Peningkatan motivasi siswa sudah nampak dengan tercapainya indikator keberhasilan penelitian, ditunjukkan dengan motivasi belajar siswa yang berkategori "tinggi" pada siklus II menjadi 92\% atau 23 siswa. Hasil belajar siswa siklus II meningkat menjadi 4 siswa atau sebesar 16\% belum tuntas, 21 siswa atau sebesar $84 \%$ telah tuntas.

Adapun peningkatan ketuntasan motivasi belajar siswa kelas IV SD Negeri 2 Bolopleret dari siklus I, hingga siklus II seperti pada tabel berikut:

Tabel 1. Presentase Motivasi Belajar Siswa Kelas III SD Negeri 2 Bolopleret

\begin{tabular}{cccccc}
\hline \multirow{2}{*}{$\begin{array}{c}\text { Interval } \\
\text { Skor }\end{array}$} & Kategori & \multicolumn{2}{c}{ Siklus 1 } & \multicolumn{2}{c}{ Siklus II } \\
\cline { 3 - 6 } & & Frekuensi & $\begin{array}{c}\text { Presentas } \\
\text { e }\end{array}$ & Frekuensi & Presentase \\
\hline $\mathbf{0 - 3 9}$ & Rendah & 0 & $0 \%$ & 0 & $0 \%$ \\
\hline $\mathbf{4 0 - 6 9}$ & Sedang & 9 & $36 \%$ & 2 & $8 \%$ \\
\hline $\mathbf{7 0 - 1 0 0}$ & Tinggi & 16 & $64 \%$ & 23 & $92 \%$ \\
\hline
\end{tabular}

Peningkatan ketuntasan motivasi belajar dari siklus I ke siklus II disajikan pada grafik berikut:

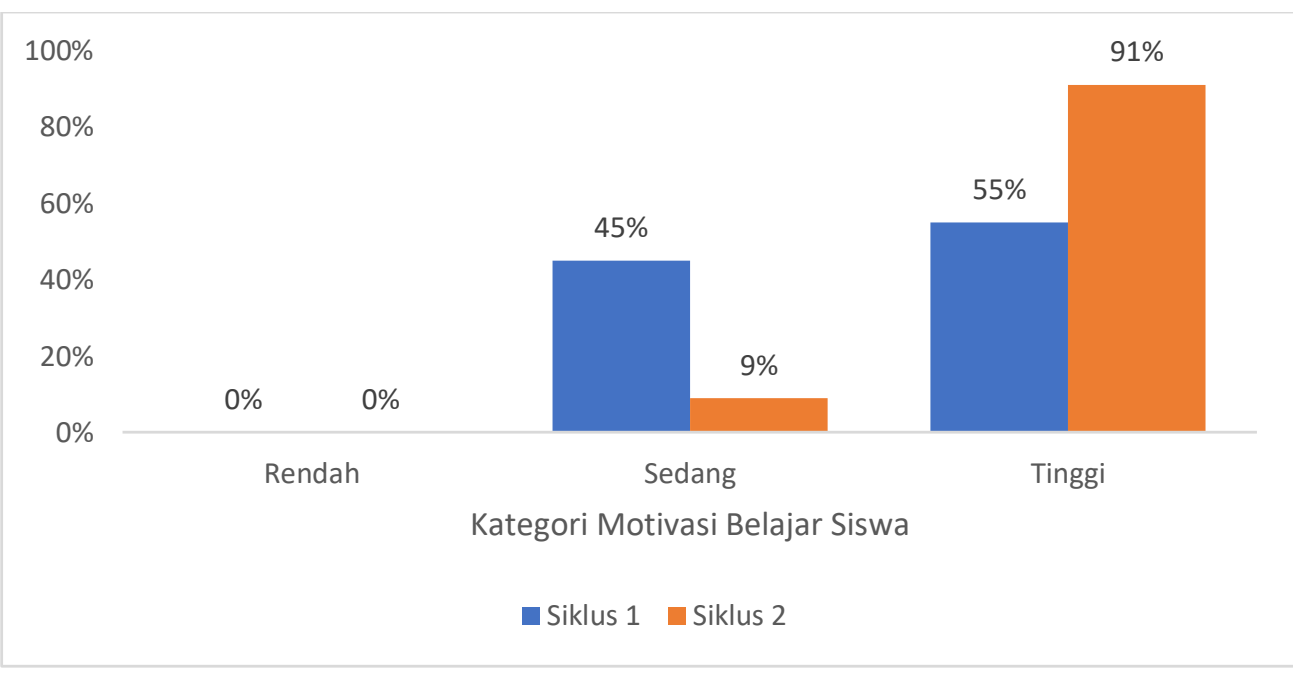

Adapun peningkatan ketuntasan hasil belajar siswa dari pra siklus sampai tindakan siklus II seperti pada tabel berikut:

Tabel 2. Persentase Hasil Belajar Siswa Kelas IV SD Negeri 2 Bolopleret $\begin{array}{llll}\text { Aspek yang diamati } & \text { Sebelum } & \text { Siklus I } & \text { Siklus II }\end{array}$

\begin{tabular}{cccc} 
& Tindakan & & \\
\hline Jumlah siswa / persentase & 8 siswa / & 14 siswa / & 21 siswa / 84 \% \\
yang telah mencapai KKM & $32 \%$ & $56 \%$ & \\
\hline Jumlah siswa / persentase & 17 siswa / & 11 siswa / 44 & 4 siswa / 16\% \\
yang belum mencapai & $68 \%$ & $\%$ & \\
KKM & & & \\
\hline
\end{tabular}


Peningkatan persentase hasil belajar dari pra siklus, siklus I ke siklus II setelah menggunakan media powerpoint interaktif disajikan pada grafik berikut:

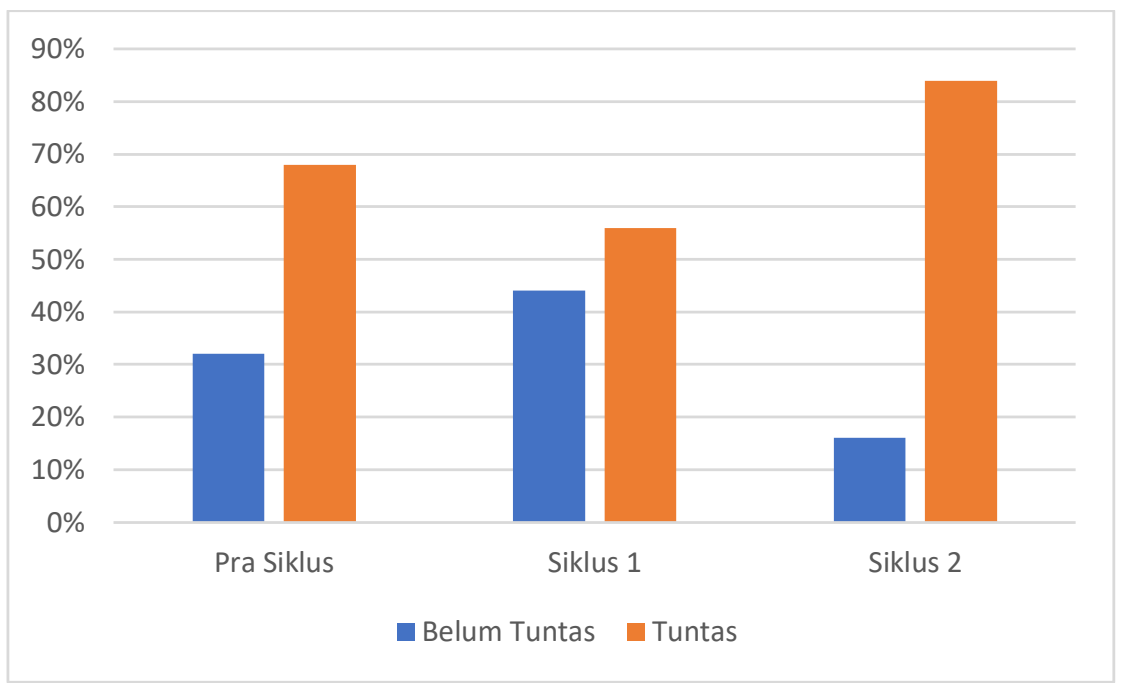

Berdasarkan observasi dan refleksi yang dilakukan guru, pada pelaksanaan pembelajaran muatan pelajaran Bahasa Indonesia dengan menggunakan model pembelajaran problem based learning telah sesuai dengan yang diharapkan. Dengan pemberian motivasi yang lebih baik, aktivitas siswa menjadi meningkat dibandingkan dengan siklus I. siswa sudah mulai terbiasa dengan bekerja bersama kelompok dan sudah bisa berdiskusi dengan anggota kelompoknya. Suasana kelas lebih terkoordinasi karena siswa antusias dalam mengikuti pembelajaran. Siswa sudah berani mengajukan pertanyaan ketika peneliti memberikan jawaban siswa masih merasa kurang puas dan mengajukan pertanyaan kembali, menjawab pertanyaan

yang diberikan oleh guru, dalam bekerja kelompok siswa mampu menganalisi argument dengan baik dan benar, siswa dan kelompok mampu memecahkan masalah dengan benar dan baik, siswa mampu membuat kesimpulan berdasarkan fakta, dan siswa mampu menilai dan mengevaluasi hasil pengamatan dengan baik dan benar sesuai fakta. Pada saat persentasi, siswa sudah berani mengemukakan pendapatnya kepada kelompok yang sedang persentasi.

Motivasi yang ada pada diri siswa dapat diketahui dengan melihat indikator motivasi belajar yang terlihat pada diri siswa. Sesuai dengan pendapat Uno (2011: 23) yang menyatakan indikator motivasi belajar meliputi adanya hasrat dan keinginan berhasil, adanya dorongan dan kebutuhan dalam belajar, adanya harapan dan cita-cita masa depan, adanya penghargaan dalam belajar, adanya kegiatan menarik dalam belajar, serta adanya lingkungan kondusif. Indikator motivasi belajar dalam penelitian ini sudah nampak diantarannya adanya dorongan dalam belajar siswa memperhatikan sungguhsungguh saat guru menjelaskan materi, guru memberikan pujian pada siswa yang menjawab pertanyaan dengan benar, siswa berkeinginan untuk mendapatkan nilai yang bagus.

Penelitian yang dilakukan oleh Habibah Sukmini, Maulana, Ali Sudin (2016) dalam Jurnal Pena Ilmiah, tahun 2016 yang berjudul "Meningkatkan Motivasi Belajar Melalui Pendekatan Problem-Based Learning (Pbl)" meskipun diterapkan pada muatan pelajaran yang berbeda terbukti model problem based learning yang dilandasi dengan pemberian masalah kepada siswa untuk dipecahkan dapat meningkatkan motivasi belajar pada kelas eksperimen dengan menggunakan pendekatan problem-based learning (PBL) 
secara signifikan lebih baik daripada kelas kontrol dengan menggunakan pendekatan konvensional.

\section{KESIMPULAN DAN SARAN}

Berdasarkan hasil penelitian yang telah dilaksanakan dalam 2 siklus dengan penerapan model problem based learning pada muatan pelajaran Bahasa Indonesia pada siswa kelas III semester II SD Negeri 2 Bolopleret Tahun Pelajaran 2020/2021 dapat disimpulkan sebagai berikut: (1) Motivasi belajar siswa yang berkategori "tinggi" pada siklus I sebesar 64\% atau 16 siswa. Pada siklus II menjadi 92\% atau 23 siswa. 2) Hasil belajar siswa sebelum tindakan hanya mencapai $32 \%$ atau 8 siswa yang tuntas. Setelah tindakan pada siklus I, sebanyak 11 siswa atau sebesar $44 \%$ belum mencapai ketuntasan belajar, 14 siswa atau sebesar $56 \%$ telah tuntas. Siklus II meningkat menjadi 4 siswa atau sebesar $16 \%$ belum tuntas, 21 siswa atau sebesar $84 \%$ telah tuntas.

Adapun saran berdasarkan hasil penelitian yang telah dilakukan, dan keterbatasan penelitian adalah model problem based learning dapat digunakan sebagai salah satu alternatif model yang terbukti dapat meningkatkan kualitas pembelajaran. Bagi guru, dalam pembelajaran guru diharapkan dapat memanfaatkan media dan model-model pembelajaran degan lebih maksimal. Bagi siswa, dalam berdiskusi kelompok hendaknya siswa aktif dan harus berani mengemukakan pendapat, pertanyaan, argumen maupun memberikan jawaban. Bagi peneliti lain, penelitian ini dapat digunakan sebagai acuan kepada peneliti selanjutnya pada bidang yang sama.Isi simpulan merupakan rumusan jawaban dari tujuan penelitian bukan rangkuman hasil penelitian

\section{UCAPAN TERIMAKASIH}

Alhamdulillahirabilalamin, puji syukur penulis panjatkan ke hadirat Allah SWT atas segala rahmat dan karunia-Nya sehingga proses penyusunan artikel ini dapat diselesaikan. Penulis juga berterimakasih kepada pihak-pihak yang turut serta mendukung kelanjaran dalam penyusunan ini, tak lupa penulis sampaikan terimakasih kepada SD Negeri 2 Bolopleret.

\section{REFERENSI}

Arikunto, S. 2010. Prosedur Penelitian Suatu Pendekatan Praktik. Jakarta: Rineka Cipta.

Fakhriyah, F. (2014). Penerapan Model Problem Based Learning dalam Upaya Mengembangkan Kemampuan Berpikir Kritis Mahasiswa. Jurnal Pendidikan IPA Indonesia, 3(1), 95-101.

Habibah Sukmini Arief, Maulana, Ali Sudin. (2016). Meningkatkan Motivasi Belajar Melalui Pendekatan Problem-Based Learning (Pbl). Jurnal Pena Ilmiah: Vol. 1, No. 1

Hamzah B. Uno. 2011. Teori Motivasi dan Pengukurannya: Analisis di Bidang Pendidikan. Bumi Aksara. Jakarta.

Rahmadani, N., \& Anugraheni, I. (2017). Peningkatan Aktivitas Belajar Matematika melalui Problem Based Learning Bagi Siswa Kelas 4 SD. Sholaria: Jurnal Pendidikan dan Kebudayaan, 7(3), 241-250.

Rahmawati , A., \& Hizqiyah , I. N. (2017, Juni). Implementasi Model Pembelajaran Problem Based Learning untuk Meningkatkan Penguasaan Defisiensi Nutrisi Tumbuhan pada Mahasiswa Pendidikan Biologi Universitas Pasundan. J. Bio \& Pend.Bio, 2, No.1, 21-25. 
Surat Edaran Kemendikbud No. 4 Tahun 2020. Pelaksanaan KebijakanPendidikan dalam Masa Darurat Penyebaran Corona Virus Disease Covid 19. Diakses pada 6 April 2021 dari https://pusdiklat.kemdikbud.go.id/surat-edaranmendikbud-no-4-tahun2020-tentang-pelaksanaan-kebijakan-pendidikandalam-masa-daruratpenyebaran-corona-virus-disease-covid-1-9/

Suttrisno, S., Riyanto, Y., \& Subroto, W. T. (2020). Pengaruh Model Value Clarification Technique (Vct) Berbasis Kearifan Lokal Terhadap Motivasi Belajar Dan Hasil Belajar Siswa. NATURALISTIC: Jurnal Kajian Penelitian Pendidikan dan Pembelajaran, 5(1), 718-729.

Yanto, Medi. 2013. Jadi Guru yang Jago Penelitian Tindakan Kelas. Yogyakarta: Andi Offset. 